\title{
Doktryna cartel facilitator - początek oraz rozwój w praktyce decyzyjnej zagranicznych organów ochrony konkurencji oraz orzecznictwie sądów unijnych
}

\section{Spis treści}

I. Wprowadzenie

II. Praktyka decyzyjna Komisji Europejskiej

1. Pierwsze rozstrzygnięcia spraw z udziałem cartel facilitators

2. Przełomowa sprawa Organic Peroxides - nałożenie symbolicznej grzywny na przedsiębiorstwo doradcze

3. Sprawa Deltafina

4. Sprawa Marine Hoses

5. Sprawa AC Treuhand II

6. Sprawa ICAP

III. Wpływ doktryny cartel facilitator na praktykę decyzyjną krajowych organów ochrony konkurencji

1. Praktyka decyzyjna holenderskiego organu ds. ochrony konkurencji

2. Praktyka decyzyjna litewskiego organu ochrony konkurencji - sprawa Eturas

3. Praktyka decyzyjna brytyjskiego organu ochrony konkurencji

IV. Podsumowanie

\section{Streszczenie}

Celem artykułu jest przedstawienie zagadnienia doktryny „cartel facilitator” w oparciu o praktykę decyzyjną zagranicznych, europejskich organów ochrony konkurencji oraz orzecznictwa sądów unijnych. Artykuł stanowi próbę przybliżenia działań podmiotów trzecich, zakwestionowanych przez organy ochrony konkurencji i zakwalifikowanych jako rodzaj pomocnictwa w niedozwolonej wymianie informacji pomiędzy przedsiębiorcami. Na gruncie przedmiotowej praktyki wypracowane zostały kryteria, które muszą zostać spełnione, aby móc pociągnąć tego typu podmioty do odpowiedzialności z tytułu naruszenia prawa konkurencji.

Słowa kluczowe: cartel facilitator; odpowiedzialność; antykonkurencyjne porozumienia.

JEL: K21

\footnotetext{
* Radca prawny; członek Okręgowej Izby Radców Prawnych w Warszawie; absolwent studiów prawniczych na UW oraz podyplomowych studiów z zakresu ochrony konkurencji na PAN. Specjalizuje się w sprawach z obszaru ochrony konsumentów, prawa antymonopolowego oraz ochrony danych osobowych. https://orcid.org/0000-0002-9857-6619.
} 


\section{Wprowadzenie}

Organy stojące na straży ochrony konkurencji, w swych działaniach wymierzonych w walkę z kartelami, od dawna przejawiają skłonność do rozszerzającej interpretacji granic zakazu niedozwolonych porozumień. Działania te mają na celu nie tylko objęcie zakazem jak najszerszego zbioru niedozwolonych zachowań, lecz także zakreślenie możliwie szerokiego kręgu podmiotów, które mogłyby ponosić odpowiedzialność za naruszenie prawa konkurencji. W ten sposób obiektem wzmożonego zainteresowania organów ochrony konkurencji stały się podmioty trzecie, nieprowadzące działalności na rynku właściwym objętym porozumieniem, których działania podejmowane w ramach świadczonych usług na rzecz uczestników porozumienia, ułatwiają popełnianie naruszeń prawa konkurencji, tzw. cartel facilitators.

Niniejszy artykuł stanowi próbę przybliżenia działań podmiotów trzecich, zakwestionowanych przez organy ochrony konkurencji i zakwalifikowanych jako rodzaj pomocnictwa w niedozwolonej wymianie informacji pomiędzy przedsiębiorcami. Na gruncie przedmiotowej praktyki wypracowane zostały kryteria, które muszą zostać spełnione, aby móc pociągnąć tego typu podmioty do odpowiedzialności z tytułu naruszenia prawa konkurencji.

\section{Praktyka decyzyjna Komisji Europejskiej}

\section{Pierwsze rozstrzygnięcia spraw $z$ udziałem cartel facilitators}

Po raz pierwszy w praktyce decyzyjnej Komisji Europejskiej (dalej: KE) problem odpowiedzialności podmiotów trzecich za wspomaganie funkcjonowania kartelu został dostrzeżony w sprawie Italian Cast Glass ${ }^{1}$. Sprawa ta dotyczyła zmowy na rynku szkła lanego we Włoszech zawartej pomiędzy największymi krajowymi producentami tych wyrobów. Porozumienie dotyczyło podziału wielkości produkcji i sprzedaży szkła lanego. Producenci postanowili wymieniać się informacjami handlowymi, które zwykle nie są i nie powinny być dzielone pomiędzy konkurentami, takimi jak wrażliwe informacje handlowe związane z polityką produkcyjną i marketingową. Producenci szkła lanego nie wymieniali się jednak informacjami bezpośrednio między sobą, lecz właśnie za pośrednictwem strony trzeciej - niezależnego zewnętrznego przedsiębiorstwa Fides z siedzibą w Mediolanie (dalej: Fides Milan).

KE zauważyła, że choć Fides Milan nie było bezpośrednio zaangażowane w produkcję czy dystrybucję szkła, to umożliwiło i świadomie wspomogło wprowadzenie w życie ograniczeń konkurencji. W konsekwencji, w treści decyzji potwierdzono współodpowiedzialność tego doradcy za naruszenie prawa konkurencji.

Z uwagi na charakter porozumienia, jego ograniczone wdrożenie w życie oraz specyfikę stanu faktycznego sprawy ${ }^{2}$, KE nie nałożyła na żaden podmiot uczestniczący w omawianym kartelu sankcji finansowych. Zastrzegając jednocześnie, że w sytuacji, gdyby zdecydowała się na nałożenie grzywien na producentów, którzy zawarli niedozwolone porozumienie, to również Fides Milan musiałoby zostać wzięte pod uwagę w zakresie ich wspólnej odpowiedzialności. Wówczas, przy ocenie wagi naruszenia prawa przez Fides Milan, KE wzięłaby pod uwagę fakt,

\footnotetext{
Dec. KE z 17.12.1980 r., IV/29.869.

2 Porozumienie stanowiące przedmiot sprawy Italian Cast Glass rozpatrywane było jako tzw. kartel kryzysowy. Szerzej na ten temat wypowiedział się A. Maziarz (2013) w artykule pt. „Kartele kryzysowe w unijnym prawie konkurencji”.
} 
iż nigdy dotąd nie skierowała decyzji do podmiotu odgrywającego analogiczną rolę w kartelu, jak Fides Milan.

Italian Cast Glass była pierwszą sprawą, w której Komisja Europejska zaadresowała decyzję do „dostawcy usług”. W latach 80. i 90. XX wieku, KE wydała kilka następnych rozstrzygnięć, w których świadczenie usług potraktowano jako wspomaganie kartelu, jednakże bez skutku w postaci pociągnięcia takich usługodawców do odpowiedzialności.

Mowa tu m.in. o sprawie Polypropylene ${ }^{3}$. Producenci polipropylenu wymieniali się co miesiąc informacjami na temat produkcji, sprzedaży oraz ruchach magazynowych za pośrednictwem dostawcy usług - przedsiębiorstwa Fides Trust Company z siedzibą w Zurychu (dalej: Fides). Chociaż, w przeciwieństwie do sprawy Italian Cast Glass, Fides nie było adresatem decyzji, to jednak wynika z niej, że mechanizm wymiany informacji za jego pośrednictwem naruszał przepisy prawa konkurencji.

Także w sprawie Cartonboard, uczestnicy zmowy - producenci kartonu - wspomagali kartel poprzez wymianę informacji za pośrednictwem Fides ${ }^{4}$. Uczestnicy kartelu dostarczali Fides okresowe raporty na temat zamówień, produkcji, sprzedaży oraz wykorzystania zdolności produkcyjnych. Raporty te były opracowywane w ramach systemu Fides, a dane zbiorcze wysyłane do uczestników porozumienia. System ten, co prawda, miał jedynie pokazywać informacje z podziałem na kraje, bez wskazywania poszczególnych producentów. W rzeczywistości jednak, w wielu przypadkach wprost ujawniono dane indywidualnych podmiotów bądź też można je było odczytać po przeprowadzeniu analizy dostarczonych danych.

Zdaniem KE, skutkiem zastosowania systemu wymiany informacji było co najmniej ułatwienie funkcjonowania kartelu. Stanowił on swoiste „narzędzie wspomagające”, które ułatwiło producentom kartonu koordynację ich działalności handlowej, w sposób sprzeczny z prawem konkurencji. Komisja nakazała uczestnikom postępowania wprowadzenie zmian w systemie wymiany informacji, tak aby był on prowadzony w szczególności sposób uniemożliwiający zidentyfikowanie zachowań poszczególnych producentów ${ }^{5}$.

\section{Przełomowa sprawa Organic Peroxides - nałożenie symbolicznej grzywny na przedsiębiorstwo doradcze}

W sprawie Organic Peroxides (nadtlenki organiczne), Komisja Europejska stwierdziła naruszenie prawa przez przedsiębiorstwo doradcze AC Treuhand ${ }^{6}$ i nałożyła na nie symboliczną sankcję finansową w wymiarze 1000 euro $^{7}$.

AC Treuhand pośredniczyło w zmowie producentów nadtlenków organicznych. Celem kartelu było przede wszystkim utrzymanie udziałów w rynku przez zaangażowanych w kartel producentów oraz koordynowanie wprowadzanych przez nich podwyżek cen.

Na podstawie umów o świadczenie usług, zawartych z trzema producentami nadtlenków organicznych AC Treuhand było zobowiązane m.in. do przechowywania w swoich pomieszczeniach niektórych tajnych dokumentów dotyczących kartelu, do gromadzenia i przetwarzania określonych

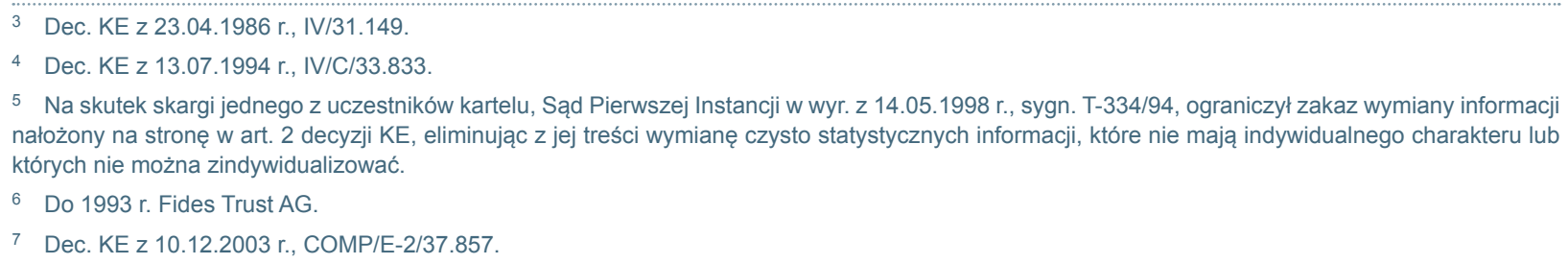


danych na temat działalności handlowej tych producentów i informowania ich o wynikach tych obliczeń, jak również do wykonywania zadań z zakresu logistyki i obsługi administracyjnej związanych z organizowaniem spotkań producentów.

W ocenie KE porozumienie zawarte między producentami nadtlenków organicznych oraz umowy o świadczenie usług zawarte między nimi a AC Treuhand stanowiły istotne elementy ogólnego i jednolitego kartelu. Z uwagi na okoliczność, iż umowy te miały na celu wykonanie porozumienia producentów nadtlenków organicznych, należało je - zdaniem Komisji - oceniać łącznie z tym porozumieniem jako porozumienia uzupełniające i dodatkowe. AC Treuhand, opłacane za pomoc we wdrożeniu i funkcjonowaniu niedozwolonego porozumienia pomiędzy producentami, stało się beneficjentem ich zmowy. KE zaakcentowała jego aktywne zaangażowanie w organizację kartelu, a także określiła AC Treuhand mianem „strażnika” prawidłowego wprowadzania kartelu w życie (pkt 343 decyzji KE).

Komisja przyznała, że co prawda, już w sprawie Italian Cast Glass skierowała decyzję do przedsiębiorstwa doradczego, to jednak w części spraw rozstrzyganych później, praktyka ta nie była stosowana. W rezultacie, z uwagi na występujący w omawianej sprawie „element nowości” w zakresie roli jaką odgrywała spółka w naruszeniu prawa konkurencji, KE zdecydowała się nałożyć na AC Treuhand grzywnę jedynie w symbolicznej wysokości (pkt 454 decyzji KE).

Wydaniu i doręczeniu zaskarżonej decyzji towarzyszył komunikat prasowy, w którym Komisja Europejska ostrzegła, że:

Kara zastosowana [względem skarżącej] ma ograniczoną wysokość z powodu nowej polityki stosowanej w tym zakresie. Przesłanie jest jednak jasne: podmioty organizujące lub ułatwiające funkcjonowanie kartelu, a więc nie tylko jego członkowie, powinny odtąd obawiać się, że ich działania zostaną wykryte i że nałożone na nie zostaną bardzo wysokie kary ${ }^{8}$. [pogrubienie własne]

Na skutek odwołania AC Treuhand od decyzji Komisji, sprawa ta stała się przedmiotem oceny Sądu Pierwszej Instancji ${ }^{9}$ (dalej: wyrok w sprawie AC Treuhand I). W odwołaniu AC Treuhand akcentowało okoliczność, iż podmiot ten nie prowadził działalności gospodarczej na rynku objętym naruszeniem ograniczającym konkurencję (tj. nie był producentem nadtlenków organicznych), a także fakt, iż we wcześniejszych sprawach, takich jak Polypropylene, podobne zachowania nie były sankcjonowane.

Sąd Pierwszej Instancji podzielił jednak zdanie Komisji co do aktywnego przyczynienia się AC Treuhand do wprowadzania kartelu w życie oraz opowiedział się za koncepcją ponoszenia odpowiedzialności przez cartel facilitators ${ }^{10}$. Dodał przy tym także, że każde przedsiębiorstwo, które podjęło pewne zachowania w ramach zmowy, w tym przedsiębiorstwa doradcze, które nie prowadzą działalności na właściwym rynku objętym ograniczeniem konkurencji, mogło rozsądnie przewidywać, że zakaz zawierania antykonkurencyjnych porozumień, co do zasady znajdował wobec niego zastosowanie ${ }^{11}$.

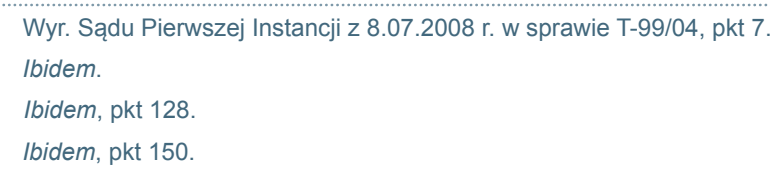


Sąd Pierwszej Instancji powołał się przy tym na dotychczasowe orzecznictwo dotyczące przesłanek, od których spełnienia zależy stwierdzenie odpowiedzialności podmiotu jako współsprawcy naruszenia prawa konkurencji, które następnie odniósł do oceny zachowania AC Treuhand. Ustalenie odpowiedzialności współsprawcy naruszenia sprowadzone zostało do oceny dwóch przesłanek, tj. przesłanki obiektywnej i przesłanki subiektywnej. Zdaniem Sądu Pierwszej Instancji, obiektywna przesłanka zachodzi, gdy przedsiębiorstwo to przyczyniło się do wprowadzenia w życie kartelu, chociażby poprzez podporządkowanie się mu w sposób pomocniczy lub bierny (np. poprzez milczącą akceptację i niepowiadomienie właściwych organów o istnieniu kartelu). Ewentualne ograniczone znaczenie tego przyczynienia się może być uwzględnione przy określaniu wysokości sankcji. Z kolei, subiektywna przesłanka zachodzi, gdy przedsiębiorstwo wyraża własną wolę, wskazującą, że popiera ono cele kartelu, chociażby milcząco ${ }^{12}$.

Powyższy test znajduje zastosowanie również do przedsiębiorstwa doradczego, które, przez wzgląd na prowadzoną przez siebie działalność gospodarczą i doświadczenie zawodowe, nie może pozostawać nieświadome antykonkurencyjnego charakteru porozumienia podmiotów, na rzecz których świadczy usługi, tym sposobem przyczyniając się do popełnienia naruszenia. Odnosząc powyższe do sytuacji AC Treuhand, Sąd Pierwszej Instancji stwierdził, że:

skarżąca z pełną świadomością sytuacji oraz umyślnie udostępniła kartelowi swoją profesjonalną ekspertyzę oraz infrastrukturę, aby osiągnąć, chociażby pośrednio, korzyść w ramach wykonania indywidualnych umów o świadczenie usług, które zawierała z trzema producentami nadtlenków organicznych. Niezależnie bowiem od kwestii, czy skarżąca w ten sposób świadomie naruszyła również reguły deontologii, jakim podlega jako konsultant gospodarczy, nie mogła ona nie wiedzieć albo też wiedziała z całą oczywistością o antykonkurencyjnym i bezprawnym celu kartelu, do którego funkcjonowania się przyczyniała; cel ten przejawiał się w szczególności w ramach porozumienia z 1971 r. i porozumienia z 1975 r., które przechowywała w swoich pomieszczeniach, w odbywaniu spotkań o antykonkurencyjnym celu oraz w wymianie wrażliwych informacji, w której czynnie uczestniczyła ona przynajmniej do 1995 lub 1996 r. (pkt 156 wyroku) [pogrubienie własne].

W ocenie Sądu Pierwszej Instancji, Komisja Europejska nie przekroczyła również swoich uprawnień odnośnie do nałożonej na AC Treuhand grzywny. Stawiane przez spółkę AC Treuhand zarzuty dotyczące naruszenia prawa do obrony, zasady ustawowej określoności czynów zabronionych i kar (nullum crimen, nulla poena sine lege), a także naruszenia zasady ochrony uzasadnionych oczekiwań, nie przyniosły zamierzonych rezultatów. Zdaniem Sądu Pierwszej Istancji praktyka decyzyjna KE po 1980 r. nie mogła zostać odczytana przez AC Treuhand jako definitywne porzucenie początkowego podejścia zastosowanego w sprawie Italian Cast Glass. Co istotne, Komisja Europejska w żadnej ze spraw nie odrzuciła bowiem samej koncepcji odpowiedzialności cartel facilitators.

\section{Sprawa Deltafina}

Na marginesie rozważań dotyczących odpowiedzialności przedsiębiorstwa doradczego wskazać należy na sprawę Deltafina, gdzie Sąd, rozpoznając sprawę kartelu na hiszpańskim 
rynku surowca tytoniowego powołał się na wyrok w sprawie AC Treuhand 113. W sprawie tej potwierdzono odpowiedzialność z art. 101 TFUE przedsiębiorstwa, które nie było obecne na wyznaczonym w decyzji rynku właściwym ${ }^{14}$. Zasadnicza jednak różnica pomiędzy sprawą z udziałem AC Treuhand polegała na tym, że Deltafina, inaczej niż AC Treuhand, prowadziła działalność na rynku usytuowanym o szczebel niżej niż rynek, na którym miały miejsce praktyki ograniczające konkurencję. Ponadto, w zaskarżonej decyzji Komisja Europejska uznała, iż rola jaką odgrywała Deltafina w kartelu przetwórców, była rolą bezpośrednią i pierwszorzędną, która „nie ograniczała się do roli zewnętrznego koordynatora czy pomocnika"15.

Powołując się na argumentację z wyroku w sprawie AC Treuhand I odnośnie do reorientacji praktyki decyzyjnej Komisji, Sąd stwierdził, iż fakt wydania przez Komisję Europejską kilku decyzji, w których nie pociągnięto do odpowiedzialności za naruszenie art. 101 TFUE przedsiębiorstw,

które uczestniczyły we wprowadzaniu w życie kartelu, nie prowadząc przy tym jednak działalności na rynku, którego dotyczyło naruszenie, nie mógł wzbudzić po stronie Deltafiny uzasadnionego oczekiwania, że w przyszłości instytucja ta powstrzyma się od ścigania takich przedsiębiorstw i nakładania na nie sankcji. ${ }^{16}$ [pogrubienie własne]

Niestety, z uwagi na cofnięte przez spółkę odwołanie od wyroku pierwszej instancji, Trybunał Sprawiedliwości Unii Europejskiej (dalej: TSUE) nie zajął stanowiska w tej sprawie ${ }^{17}$.

\section{Sprawa Marine Hoses}

Wracając do spraw prowadzonych przez Komisję Europejską dotyczących działalności klasycznego przedsiębiorstwa doradczego, w świetle wyrażonego przez Komisję Europejską stanowiska w sprawie Organic Peroxides, zaskoczenie wywołała decyzja w sprawie Marine Hoses ${ }^{18}$. Przedmiotowa sprawa dotyczyła antykonkurencyjnego porozumienia zawartego pomiędzy producentami przewodów morskich. Decyzja KE została wydana zaledwie kilka miesięcy od daty wyroku Sądu Pierwszej Instancji w sprawie AC Treuhand I. W sprawie tej KE nie nałożyła żadnej kary ani nawet nie zaadresowała decyzji do przedsiębiorstwa konsultacyjnego PW Consulting, pomimo że zostało ono uznane za koordynatora kartelu. Przy czym, w treści uzasadnienia decyzji na jego udział i rolę w organizacji kartelu Komisja powoływała się wielokrotnie (stosując określenie ang. Cartel coordinator’s company). W związku z udziałem w kartelu, przeciwko właścicielowi PW Consulting - Peterowi Whittle'owi - zostało wszczęte postępowanie karne, w wyniku którego został on skazany na 3 lata pozbawienia wolności.

W odpowiedzi na zarzucaną niekonsekwencję Komisja, powołując się na wyjątkowe okoliczności, podnosiła, iż jej działanie miało na celu uniknięcie zarzutu naruszenia zasady zakazu podwójnego osądzenia w związku z postępowaniem karnym wobec osoby fizycznej. W doktrynie powyższe uzasadnienie zostało poddane krytyce. Podnoszono, iż takie stanowisko trudno uznać za przekonujące, skoro odpowiedzialnością karną obciążona została osoba fizyczna,

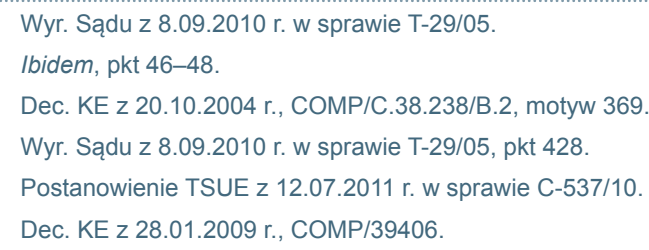


a postępowanie przed Komisją Europejską skierowane było przeciwko przedsiębiorstwom (Król-Bogomilska, 2013). Co więcej, trudno nie zgodzić się ze stanowiskiem, iż symboliczna grzywna pozostawałaby w zgodzie z dotychczasową praktyką Komisji wobec podmiotów ułatwiających kartele (Marx i Mezzetti, 2014).

\section{Sprawa AC Treuhand II}

Sprawę Marine Hoses należy potraktować jako rozstrzygnięcie o charakterze incydentalnym z punktu widzenia odpowiedzialności cartel facilitator, biorąc pod uwagę, że jeszcze w tym samym roku Komisja Europejska powróciła do praktyki decyzyjnej wypracowanej na gruncie sprawy Organic Peroxides. W kolejnym postępowaniu, tj. w sprawie Heat stabilisers ${ }^{19}$, KE nałożyła ponownie na AC Treuhand sankcję finansową. Tym razem jednak już nie w symbolicznej wysokości, a w kwocie wynoszącej 348000 EUR $^{20}$.

W rozpoznawanej sprawie $A C$ Treuhand świadczyło usługi na rzecz uczestników dwóch karteli na rynku stabilizatorów termicznych. W zamian za wynagrodzenie AC Treuhand organizowało dla nich spotkania (w których także aktywnie uczestniczyło) oraz zbierało i dostarczało dane dotyczące sprzedaży, rynków właściwych, zachęcając jednocześnie strony do zawierania kompromisów.

W pierwszej instancji, Sąd oddalił skargę AC Treuhand na decyzję KE, powołując się m.in. na wyrok w sprawie AC Treuhand ${ }^{21}$. Następnie sprawa została skierowana do Trybunału Sprawiedliwości Unii Europejskiej.

Odmienne zdanie w przedmiocie odpowiedzialności spółki doradczej na gruncie art. 81 WE [obecnie art. 101 TFUE] przedstawił w swojej opinii rzecznik generalny Nils Wahl. Stając w opozycji do stanowiska Sądu i Komisji Europejskiej, uznał, że pociągnięcie AC Treuhand do odpowiedzialności nie ma podstawy prawnej. Zdaniem rzecznika generalnego zachowania AC Treuhand nie mogły podlegać zakazowi zawierania porozumień, o których mowa w tym przepisie, z uwagi na brak wywierania przez tę spółkę presji konkurencyjnej (competitive constraint) na uczestników kartelu22.

Tymczasem Trybunał Sprawiedliwości Unii Europejskiej (nie odnosząc się do kontrargumentów przedstawionych przez rzecznika generalnego) podzielił stanowisko Komisji, uznając, że zachowanie którego dopuściło się AC Treuhand objęte jest zakazem z art. 81 ust. 1 WE [obecnie art. 101 TFUE] ${ }^{23}$. W tym celu TSUE powołał się na literalne brzmienie tego przepisu, w szczególności na użyte w nim sformułowanie: „porozumienia między przedsiębiorstwami”. Sformułowanie to nie wprowadza rozróżnienia w zależności od sektora lub rynku, na którym zainteresowane przedsiębiorstwa prowadzą działalność. TSUE przywołał także dotychczasowe orzecznictwo w sprawach „porozumień” i „uzgodnionych praktyk”. Zabiegi, którymi posłużył się dla przypisania odpowiedzialności AC Treuhand za naruszenie prawa konkurencji, ukierunkowane były na zapewnienie pełnej skuteczności (fr. effet utile) zakazu ustanowionego w art. 81 WE [obecnie 101 TFUE]. Przeciwne stanowisko nie pozostawałoby - zdaniem Trybunału - w zgodzie z celem tego przepisu, rozumianym jako zapewnienie utrzymania niezakłóconej konkurencji w obrębie wspólnego rynku.

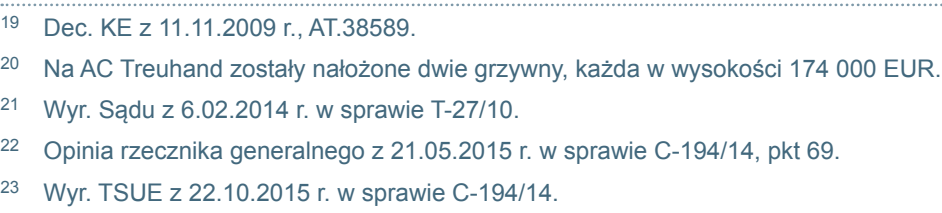


TSUE wskazał, że celem świadczonych przez spółkę usług była świadoma realizacja antykonkurencyjnych porozumień, tj. ustalanie cen, podział rynków i klientów, a także wymiana informacji handlowych. Zdaniem TSUE, działań AC Treuhand nie można było sprowadzić do prostych usług pomocniczych, niemających związku z zobowiązaniami zaciągniętymi przez producentów ani z wynikającymi z nich ograniczeniami konkurencji.

TSUE nie uwzględnił zarzutu spółki dotyczącego naruszenia przez Komisję zasady ustawowej określoności czynów zabronionych i kar. AC-Treuhand powoływało się na brak utrwalonego orzecznictwa, z którego w jasny sposób wynikałaby karalność podobnych zachowań. W ocenie TSUE, spółka ta powinna była spodziewać się, w razie potrzeby po zasięgnięciu fachowych porad, że jej zachowanie zostanie uznane za niezgodne z regułami konkurencji prawa Unii. Choć dla Trybunału wydało się to zupełnie oczywiste, wątpliwości może budzić fakt, iż rzecznik generalny zajął w tej sprawie całkowicie odmienne stanowisko. Podkreślił nawet, że jest w pełni przekonany, iż zakaz z art. 81 WE nie ma zastosowania do przedsiębiorstwa, które nie działa na danym rynku lub na rynkach powiązanych i które sensu stricto nie zawarło porozumienia ograniczającego konkurencję, ani nie prowadziło uzgodnionych praktyk na owych rynkach ${ }^{24}$. Słusznie omawianemu orzeczeniu zarzuca się lakoniczność, brak ustosunkowania się do racjonalnych argumentów podniesionych przez rzecznika generalnego oraz niewyjaśnienie szeregu wątpliwości, jakie dla praktyki niesie za sobą ten wyrok ${ }^{25}$. Cel Trybunału jednak został osiągnięty poprzez urzeczywistnienie zasady skuteczności art. 101 TFUE.

\section{Sprawa ICAP}

W następnej sprawie, KE uznała, iż spółki ICAP plc, ICAP Management Services Ltd i ICAP New Zealand Limited (dalej: ICAP) naruszyły unijne przepisy ochrony konkurencji poprzez ułatwianie funkcjonowania sześciu z siedmiu wykrytych karteli w sektorze finansowych instrumentów pochodnych stopy procentowej denominowanych w jenach (YIRD) ${ }^{26}$. ICAP, jako broker, ułatwiało antykonkurencyjne zachowania banków będących członkami kartelu27. Zakwestionowane działania polegały m.in. na pośredniczeniu w kontaktach noszących znamiona zmowy, kontaktowaniu się z innymi bankami będącymi członkami panelu ustalającego JPY LIBOR oraz rozpowszechnianiu nieprawdziwych informacji za pośrednictwem biuletynu w celu wywarcia wpływu na prognozy JPY LIBOR.

Nakładając na ICAP grzywnę w łącznej wysokości około 15 mln EUR Komisja Europejska odwołała się do pkt 37 Wytycznych z 2006 r. w sprawie ustalania grzywien ${ }^{28}$, zgodnie z którym:

(...) szczególne okoliczności danego przypadku lub konieczność osiągnięcia efektu odstraszającego w pewnym przypadku mogą uzasadnić odstąpienie Komisji od wspomnianej metodologii lub pułapów ustalonych w pkt 21.

\footnotetext{
24 Surdyk M. (2018), Odpowiedzialność przedsiębiorstwa za naruszenie prawa konkurencji dokonane przez jego współpracowników w orzecznictwie unijnym, internetowy Kwartalnik Antymonopolowy i Regulacyjny, nr 2(7).

25 Pogląd Busher, R., Herz, M. and Vedder, H. (2015), The Shortest Competition Judgment Ever: Ac-Treuhand II. - https://europeanlawblog.eu/2015/11/09/ the-shortestcompetition-judgment-ever-ac-treuhand-ii/.

26 Decyzja KE z 4.02.2015 r., AT.39861.

27 Naruszenia te zostały wcześniej stwierdzone w decyzji KE z 4.12.2013 r., AT.39861.

28 Wytyczne w sprawie metody ustalania grzywien nakładanych na mocy art. 23 ust. 2 lit. a) rozporządzenia 1/2006, (Dz. Urz. UE 2006 C 210/02).
} 
Od powyższej decyzji ICAP wniosło skargę do Sądu, zarzucając Komisji m.in. błędne zastosowanie pojęcia „ułatwiania” w rozumieniu art. 101 TFUE, naruszenie zasad domniemania niewinności i dobrej administracji oraz błędnego ustalenia kwoty grzywien. W skardze ICAP zwracała szczególną uwagę na różnicę w roli, jaką odgrywała w zarzucanych jej naruszeniach od roli jaką odgrywała AC Treuhand w sprawach będących dotychczas przedmiotem oceny KE. Zdaniem ICAP, to przedsiębiorstwo AC Treuhand sprawiło, że zmowa stała się możliwa, ICAP zaś zarzuca się jedynie to, że świadczyło usługi na rzecz uczestników zmowy lub przyczyniło się do niej, a zmowa między zainteresowanymi bankami istniałaby nawet bez żadnej jej ingerencji ${ }^{29}$.

Rozpoznając skargę i odwołując się do wyroku TSUE w sprawie AC Treuhand, Sąd potwierdził możliwość pociągnięcia cartel facilitator do odpowiedzialności z art. 101 TFUE, bazując na wypracowanych w orzecznictwie kryteriach odpowiedzialności podmiotów wspomagających działanie kartelu. Zgodnie z tymi kryteriami KE powinna udowodnić, że:

a) dane przedsiębiorstwo zamierzało przyczynić się swoim zachowaniem do wspólnych celów realizowanych przez ogół uczestników, a także

b) wiedziało ono o postępowaniu planowanym lub wprowadzanym w życie przez inne przedsiębiorstwa w dążeniu do tych samych celów lub że mogło to rozsądnie przewidzieć i było gotowe zaakceptować takie ryzyko ${ }^{30}$.

Poddając następnie analizie, czy uczestnictwo ICAP spełniało powyższe kryteria, Sąd stwierdził, że w odniesieniu do czterech rozpatrywanych naruszeń, KE zasadnie uznała, iż ICAP wiedziało o istnieniu zmowy między bankami. Ponadto, z uwagi na to, że zachowania banków i zachowanie ICAP w znacznej mierze uzupełniały się, przyjąć należało, iż ICAP miało zamiar przyczynienia się do realizacji wspólnych dla tych banków celów ${ }^{31}$.

W swojej argumentacji ICAP starało się nadać mniejsze znaczenie roli, jaką spółka odgrywała w naruszeniach, poprzez porównanie jej z rolą spółki AC Treuhand w sprawach podlegających dotychczas ocenie z punktu widzenia zgodności z prawem konkurencji. Zdaniem Sądu jednak należało, przeciwnie do sugestii ICAP, wręcz podkreślić znaczenie jej uczestnictwa dla niektórych z rozpoznawanych naruszeń:

Skoro bowiem stawki JPY LIBOR są obliczane na podstawie propozycji członków panelu, to wpływ wywierany przez przedsiębiorstwo Icap na wchodzących w skład owego panelu klientów za pomocą biuletynu, o którym mowa w pkt 15 powyżej, pozwolił na nadanie manipulacjom tymi stawkami znacznie większego rozmiaru niż ten, który miałyby one, gdyby pozostały ograniczone jedynie do propozycji dwóch banków uczestniczących w każdym z naruszeń. ${ }^{32}$

W konsekwencji, Sąd uznał, iż Komisja Europejska wykazała w wymagany prawem sposób, że ICAP uczestniczyło w pięciu z sześciu rozpatrywanych naruszeń. Stwierdził ponadto nieważność decyzji w części dotyczącej grzywny, wskazując, iż KE uzasadniając wysokość grzywny,

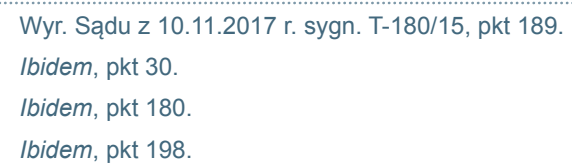


nie mogła ograniczyć się jedynie do ogólnego zapewnienia, że przyjęte kwoty podstawowe odzwierciedlają wagę, czas trwania i charakter uczestnictwa ICAP w rozpatrywanych naruszeniach oraz realizują funkcję odstraszającą. Tak ogólne stwierdzenia nie pozwalają skarżącym na ocenę zasadności zastosowanej przez Komisję metodologii, a Sądowi na przeprowadzenie jej kontroli33.

Nie zgadzając się z rozstrzygnięciem Sądu w powyższym zakresie, Komisja Europejska wniosła odwołanie do TSUE, zarzucając, iż w sposób nieprawidłowy i niemający oparcia w orzecznictwie nałożono na KE surowszy obowiązek dotyczący szczegółowego uzasadniania metody wykorzystanej przy obliczaniu grzywien nakładanych za naruszenia na gruncie art. 101 TFUE. Ostatecznie, wyrokiem z dnia 10 lipca 2019 r. w sprawie C-39/18 TSUE oddalił odwołanie Komisji Europejskiej. Nie sposób odmówić słuszności stanowisku zajętemu przez Trybunał. Komisja zawsze powinna objaśnić co najmniej sposób, w jaki dokonała wyważenia i oceny czynników, które wzięła pod uwagę przy ustalaniu wysokości grzywien, tak aby najpierw umożliwić przedsiębiorcy zapoznanie się z przyjętą przez organ metodologią, a następnie umożliwić sądowi jej weryfikację.

\section{Wpływ doktryny cartel facilitator na praktykę decyzyjną krajowych organów ochrony konkurencji}

Rozważania na temat odpowiedzialności przedsiębiorstwa doradczego na szczeblu unijnym wywarły wpływ na praktykę decyzyjną krajowych organów ochrony konkurencji. Już teraz znane są przykłady zarówno bezpośredniego zastosowania doktryny cartel facilitator, jak i spraw, w których jedynie pośrednio poruszono problematykę odpowiedzialności takich podmiotów.

\section{Praktyka decyzyjna holenderskiego organu ds. ochrony konkurencji}

Wyrok Sądu Pierwszej Instancji w sprawie AC Treuhand I wpłynął na praktykę holenderskiego organu ds. ochrony konkurencji (Nederlandse Mededingingsautoriteit, dalej: NMa), który w 2009 r. w serii czterech spraw dotyczących karteli w sektorze farb, nałożył na spółkę doradczą Calculatiebureau Coöperatieve Vereniging Spegelt U.A. (dalej: Spegelt) grzywny w łącznej wysokości 46000 EUR ${ }^{34}$. Działania podejmowane przez Spegelt polegały w szczególności na organizowaniu spotkań dla uczestników zmów przetargowych oraz sporządzaniu dokumentów zawierających dokonane ustalenia. W ten sposób zdaniem NMa Spegelt aktywnie uczestniczyło w tworzeniu tych karteli. Organ uznał, iż w rozpoznawanych sprawach przesłanki odpowiedzialności cartel facilitator wypracowane w wyroku w sprawie AC Treuhand I zostały spełnione.

Kilka lat później w sprawie Bell pepper cartel, dotyczącej zmowy producentów papryki, holenderski organ ds. ochrony konkurencji po raz kolejny nałożył sankcję finansową na podmiot uczestniczący w kartelu w charakterze cartel facilitator, tj. na przedsiębiorstwo konsultacyjne Florpartners B.V. NMa zauważył, że mimo iż Florpartners B.V. nie było aktywne na rynku sprzedaży papryki, to jednak ponosiło odpowiedzialność za naruszenie prawa konkurencji. Florpartners B.V. uczestniczyło bowiem w niedozwolonym porozumieniu, organizując i przewodnicząc antykonkurencyjnym spotkaniom,

\footnotetext{
33 Ibidem, pkt 294

34 Dec. NMa z 5.07.2009 r. nr 6431_1/172 oraz nr 6429_1/176; Dec. NMa z 21.08.2009 r. nr 6430_1/131 oraz nr 6492_1/146.
} 
sporządzając dokumenty odzwierciedlające przebieg spotkań, a także pobierając wynagrodzenie za świadczone przez siebie usługi na rzecz producentów papryki zaangażowanych w kartel. W konsekwencji została na nie nałożona grzywna w wysokości 5000 EUR ${ }^{35}$.

\section{Praktyka decyzyjna litewskiego organu ochrony konkurencji - sprawa Eturas}

Rada ds. konkurencji (litewski organ ochrony konkurencji) decyzją z dnia 7 czerwca 2012 r. uznała, że 30 biur podróży oraz spółka E-turas uczestniczyły w praktyce antykonkurencyjnej dotyczącej rabatów stosowanych dla rezerwacji dokonywanych za pośrednictwem systemu rezerwacji wycieczek on-line dostarczanego przez E-turas (dalej: system E-turas) ${ }^{36}$. W 2009 r. E-turas wprowadził w systemie zmiany techniczne ograniczające biurom podróży możliwość przyznawania rabatu przekraczającego 3\%, co było poprzedzone informacją skierowaną do biur korzystających z systemu. W ocenie Rady ds. konkurencji E-turas oraz zainteresowane biura podróży naruszyły art. 101 TFUE oraz art. 5 litewskiej ustawy o konkurencji, poprzez koordynowanie stawek rabatów oferowanych konsumentom nabywającym wycieczki on-line za pomocą systemu E-turas (stanowiącego narzędzie koordynacji antykonkurencyjnych działań). Z przedmiotowej decyzji wynika, że choć E-turas nie prowadził działalności na tym samym rynku właściwym co zaangażowane w antykonkurencyjną praktykę biura podróży, to jednak koordynacja zachowań biur podróży była możliwa właśnie dzięki aktywnym działaniom tej spółki. Zdaniem Rady ds. Konkurencji z zebranych w toku postępowania informacji wynikało, że E-turas był bezpośrednio zainteresowany tym, aby biura podróży nie udzielały wysokich rabatów. W szczególności, im niższy rabat miał zastosowanie, tym wyższe wynagrodzenie otrzymywał E-turas.

Co istotne, przy ocenie możliwości pociągnięcia E-turas do odpowiedzialności za naruszenie art. 101 TFUE Rada ds. Konkurencji powołała się na wyrok Sądu Pierwszej Instancji w sprawie AC Treuhand I i wskazane w nim przesłanki odpowiedzialności, które w ocenie Rady ds. Konkurencji zostały w tym konkretnym przypadku spełnione.

Na E-turas ostatecznie została nałożona grzywna, która uwzględniała okoliczność, iż E-turas był inicjatorem antykonkurencyjnej praktyki. W związku ze skierowanym przez Najwyższy Sąd Administracyjny Litwy pytaniem prejudycjalnym, w sprawie tej miał sposobność wypowiedzieć się TSUE. Przedmiotem pytania sądu krajowego nie była jednak odpowiedzialność E-turas, jako podmiotu ułatwiającego wprowadzenie w życie kartelu, a interpretacja pojęcia praktyki uzgodnionej $z$ art. 101 ust. 1 TFUE $^{37}$.

Do sprawy E-turas odwołano się m.in. dokumencie UE dla OECD w przedmiocie tzw. porozumień hub and spoke ${ }^{38}$. Odrębnie poruszono w nim kwestię uczestnictwa w niedozwolonym porozumieniu platformy on-line jako podmiotu ułatwiającego nawiązanie i funkcjonowanie kartelu. Zwrócono uwagę, iż informatyzacja działań w sposób łatwy pozwala m.in. na wymianę wrażliwych informacji handlowych oraz ustalanie cen pomiędzy przedsiębiorcami, bez ich jednoczesnej fizycznej obecności. Zauważono ponadto, iż w tym wypadku, platforma on-line mogłaby zostać pociągnięta do odpowiedzialności w oparciu o doktrynę „cartel facilitator".

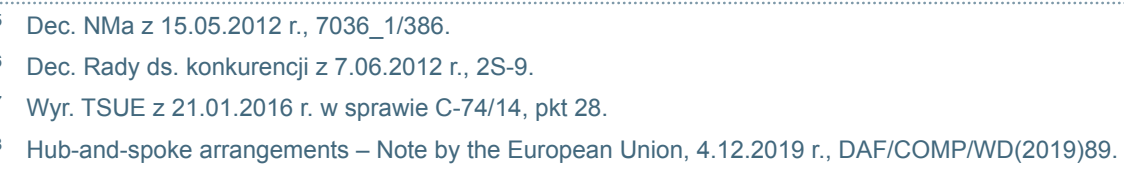




\section{Praktyka decyzyjna brytyjskiego organu ochrony konkurencji}

Oceniając wpływ ostatnich orzeczeń dotyczących odpowiedzialności cartel facilitator na dalszą praktykę krajowych organów ochrony konkurencji, wskazać można na zachowawcze działanie brytyjskiego organu ochrony konkurencji (Competition and Markets Authority; dalej: CMA). CMA w 2016 r. wydał decyzję, w której uznał, że dwa przedsiębiorstwa (Trod i GBE) naruszyły reguły prawa konkurencji, uczestnicząc w kartelu na rynku sprzedaży plakatów za pośrednictwem serwisu Amazon. Uczestnicy kartelu zobowiązali się do niekonkurowania ze sobą przy sprzedaży plakatów na brytyjskiej wersji platformy internetowej Amazon ${ }^{39}$. W celu przestrzegania postanowień zawartego porozumienia wykorzystywany był odpowiednio skonfigurowany algorytm cenowy (zautomatyzowane oprogramowanie), który monitorował i ustalał ceny na odpowiednim poziomie. Na Trod została nałożona kara pieniężna w wysokości ok. £160000, natomiast GBE uniknął sankcji dzięki skorzystaniu z programu łagodzenia kar leniency.

CMA w uzasadnieniu decyzji, jedynie na marginesie wskazał, że co prawda rozważał czy zbadać zaangażowanie dostawcy oprogramowania w naruszenie prawa konkurencji (w tym czy dostawca oprogramowania mógł ułatwić porozumienie między Trod i GBE), ostatecznie jednak organ przyjął, iż nie stanowiło to priorytetu administracyjnego. W informacji prasowej na oficjalnej stronie internetowej organu CMA skierował zaadresowane ogólnie do dostawców oprogramowania ostrzeżenie, wskazując, że jeżeli będą oni pomagać swoim klientom w wykorzystywaniu dostarczanego oprogramowania w celu wspomagania niedozwolonych porozumień cenowych, to również oni ponosić będą ryzyko naruszenia prawa konkurencji (choć nie było to przedmiotem postępowania w sprawie zmowy pomiędzy Trod i GBE $)^{40}$.

Z kolei w 2015 r. CMA wydał decyzję w sprawie antykonkurencyjnego porozumienia, którego przedmiotem było ograniczenie możliwości reklamowania usług agentów sprzedaży i najmu nieruchomości w lokalnej gazecie „Surrey \& Hants Star Courier”. W decyzji tej brytyjski organ ochrony konkurencji uznał za stronę porozumienia również wydawcę „Surrey \& Hants Star Courier”, choć wydawca ten nie był aktywny na rynku obrotu nieruchomościami i działał niejako „pod presją” innych uczestników niedozwolonego porozumienia ${ }^{41}$. Po przeprowadzeniu postępowania w tej sprawie CMA opublikował na swojej stronie internetowej informację, w której, odnosząc się do wyroku w sprawie AC Treuhand II, wezwał podmioty, do których zwrócono się w przedmiocie ułatwienia lub wprowadzenia w życie niedozwolonego porozumienia, do przeprowadzenia oceny własnych zachowań z punktu widzenia prawa konkurencji oraz do zgłaszania CMA informacji o antykonkurencyjnych praktykach ${ }^{42}$.

\section{Podsumowanie}

Doszukiwanie się odpowiedzialności podmiotów trzecich z tytułu niedozwolonych porozumień sięga swoimi korzeniami już lat 80 . XX wieku. Jednak dopiero stosunkowo niedawno praktyka pociągania takich podmiotów do odpowiedzialności, w tym nakładania na nie odczuwalnych sankcji finansowych, stała się wyraźniej widoczna w działalności decyzyjnej Komisji

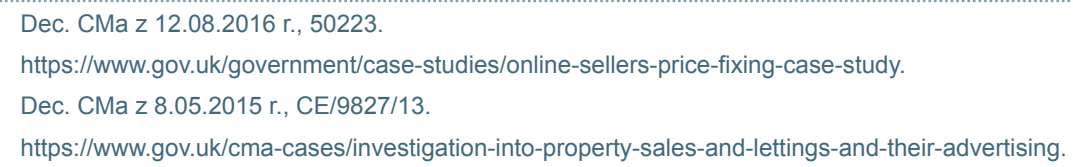


Europejskiej, jak i [póki co] pojedynczych krajowych organów ochrony konkurencji. Co więcej, za sprawą ostatnich orzeczeń Trybunału Sprawiedliwości Unii Europejskiej, zasadnym staje się przypuszczenie, że również kolejne krajowe organy ochrony konkurencji pójdą w ślad za kierunkiem wyznaczonym przez Komisję Europejską i spraw z udziałem cartel facililators będzie znacznie więcej.

Obecnie w orzecznictwie unijnym jednolicie przyjmowany jest pogląd, zgodnie z którym dla ponoszenia odpowiedzialności przez podmiot trzeci (tj. usługodawcę, przedsiębiorstwo doradcze) z tytułu naruszenia prawa konkurencji - a konkretnie art. 101 TFUE - nie jest konieczne, aby podmiot ten prowadził działalność na rynku objętym naruszeniem. Co więcej, dotyczy to zarówno usług świadczonych w formie tradycyjnej (organizowanie spotkań, sporządzanie dokumentacji, pośredniczenie w kontaktach między konkurentami), jak i przy wykorzystaniu systemu on-line jako platformy dla wprowadzenia w życie niedozwolonych praktyk. W orzecznictwie sądów unijnych wypracowano kryteria pozwalające na pociągnięcie tego typu podmiotów do odpowiedzialności. W tym celu konieczne jest udowodnienie przez organ, że dane przedsiębiorstwo zamierzało przyczynić się swoim zachowaniem do wspólnych celów realizowanych przez ogół uczestników porozumienia. Ponadto należałoby wykazać, iż wiedziało ono o postępowaniu planowanym lub wprowadzanym w życie przez inne przedsiębiorstwa w dążeniu do tych samych celów lub że mogło to rozsądnie przewidzieć i było gotowe zaakceptować takie ryzyko. Niewątpliwie przesłanki te zostały określone na tyle szeroko, aby zapewnić pełną skuteczność (fr. effet utile) zakazu ustanowionego w art. 101 TFUE.

\section{Bibliografia}

Aalst, E., Reznitchenko, A. i Putter, M. (2009). Dutch Cartel Law. The European Antitrust Review. Pozyskano z: https://globalcompetitionreview.com/insight/the-european-antitrust-review-2009/1064912/dutch-cartel-law.

Bael, I. (2011). Due Process in EU Competition Proceedings. Hague-London-New York: Kluwer Law International.

Bolecki, A. (2011). Polish Antitrust Experience with Hub-and-Spoke Conspiracies. YARS, 4.

Bolecki, A. (2011). Wymiana informacji między konkurentami w świetle prawa ochrony konkurencji. Przegląd Prawa Handlowego, 1.

Busher, R., Herz, M. i Vedder, H. (2015). The Shortest Competition Judgment Ever: Ac-Treuhand II. Pozyskano z: https://europeanlawblog.eu/2015/11/09/the-shortestcompetition-judgment-ever-ac-treuhand-ii/.

Canu, V. (2015). EU's highest court confirms liability of cartel facilitators. Pozyskano z: http://competitionlawblog.kluwercompetitionlaw.com/2015/10/29/eus-highest-court-confirms-liability-of-cartel-facilitators.

Hobbelen, H., Lorje, N. i Guenay, A. (2016). Selected Recent developments in the application of EU competition law to online platforms. Mediaforum. Pozyskano z: https://www.sipotra.it/wp-content/uploads/2016/11/ Selected-recent-developments-in-the-application-of-EU-competition-law-to-online-platforms.pdf.

Hobbelen, H. (2015). Antitrust Enforcement in Traditional v. Online Platforms. Platforms as facilitators of concerned practices - introduction to panel. Workshop Entrance for Executives, 4th-5th December. European University Institute San Domenico di Fiesole, Florence. Pozyskano z: https://core.ac.uk/ download/pdf/45687551.pdf.

Knapp, M. (2018). Liability for Anti-Competitive Conduct of a Third Party under EU Competition Law. YARS, 11(17). 
Król-Bogomilska, M. (2013). Zwalczanie karteli w prawie antymonopolowym i karnym. Warszawa: Wydawnictwo Naukowe Scholar.

Marx, L. i Mezzetti, C. (2014). Effects of Antitrust Leniency on Concealment Effort by Colluding Firms. Journal of Antitrust Enforcement, 2.

Maziarz, A. (2013). Kartele kryzysowe w unijnym prawie konkurencji. Przegląd Ustawodawstwa Gospodarczego, 10.

Stasi, M.L. i Parcu, P.L. (2016). Antitrust Enforcement in Traditional v Online Platforms. Workshop Entrance for Executives, 4th-5th December. European University Institute San Domenico di Fiesole, Florence. Pozyskano z: https://core.ac.uk/download/pdf/45687551.pdf.

Surdyk, M. (2018). Odpowiedzialność przedsiębiorstwa za naruszenie prawa konkurencji dokonane przez jego współpracowników w orzecznictwie unijnym. internetowy Kwartalnik Antymonopolowy i Regulacyjny, 2(7). 